\title{
SOCIABILIDADE HOMOERÓTICA E RELAÇÕES IDENTITÁRIAS: o caso do jornal O Snob (Rio de Janeiro, década de 1960)
}

\author{
Rogerio da Silva Martins da Costa*
}

\section{Resumo}

Este artigo estuda uma rede de sociabilidade homoerótica na cidade do Rio de Janeiro, na década de 1960, pela análise de relatos contidos no jornal doméstico O Snob (1963 a 1969), produzido por um dos grupos que formavam essa rede e que circulava entre os seus participantes. Trata-se de uma investigação das construções identitárias que esses personagens realizaram em um espaço de sociabilidade segregado da sociedade maior, mas ao mesmo tempo dialogando com ela. Analisando os assuntos que esses grupos abordaram internamente, tendo como pano de fundo as normas heterocentradas de comportamento vigentes no período, identifiquei experimentos originais em busca de um "corpo homossexual normal”. As mudanças sociossexuais promovidas por esses experimentos refletiram-se nos seus espaços de sociabilidade e nas parcerias sexuais estabelecidas, propiciando o surgimento de novas possibilidades sexuais e/ou afetivas. Assim, tento demonstrar que a forma de integração empreendida pelos grupos em estudo estava diretamente ligada a certa inflexibilidade dos papéis de gênero da época, rigidez que com o tempo foi se distanciando das antigas para construir novas maneiras de atuar. Estudar a trajetória peculiar dos grupos que formavam a rede, associando-a aos movimentos identitários próprios de seu tempo, pode contribuir para discutir a história dos direitos individuais, mais especificamente da luta pela igualdade sexual, e para o debate sobre ocupação de espaços gays.

Palavras-chave: Sociabilidades. Homoerotismo. Relações de gênero. Imprensa.

\section{Introdução}

Este artigo estuda uma rede de sociabilidade homoerótica ${ }^{1}$ na cidade do Rio de Janeiro na década de 1960, analisando o jornal $O$ Snob - jornal doméstico de temática "homossexual”² -, idealizado e produzido por Agildo Guimarães³ no período de 1963 a 1969.

\footnotetext{
* Mestre em Bens Culturais e Projetos Sociais pelo Programa de História, Política e Bens Culturais da Fundação Getúlio Vargas. Professor da disciplina Ciências Sociais e Sexualidade na especialização em Sexualidade Humana do Centro Universitário Hermínio da Silveira UniIBMR. E-mail: rogeh.martins@gmail.com

${ }^{1}$ Uso o adjetivo homoerótica seguindo Costa (1992), pois qualifica um número maior de pessoas, independente de como se designem sexualmente. Prefiro este termo, já que nesses grupos havia "homens que faziam sexo com homens" que não necessariamente se consideravam ou eram considerados homossexuais.

${ }^{2}$ Nesse período e na rede estudada, esta designação só era imputada aos homens que mantinham práticas sexuais "passivas", ou seja, aqueles que eram penetrados por outro homem.

${ }^{3}$ Além de ser o idealizador de $O$ Snob, é remanescente da fundação de um dos grupos no período de 1961-1964 (Turma OK). Nos anos de 1970, publicou o jornal Gente Gay e colaborou com a edição n. 28, 1980, do jornal
} 
Trata-se de uma investigação da trajetória das identidades que os personagens dessa rede conseguiram construir, embora segregados, num espaço de sociabilidade próprio, mas de onde, ao mesmo tempo, procuravam manter-se em diálogo com a sociedade maior.

Os grupos promoviam reuniões festivas que propiciaram o surgimento de um espaço específico de reconhecimento/pertencimento (gueto), que se contrapunha às situações adversas impostas pela sociedade em geral, possibilitando o estreitamento das relações de seus participantes com base numa identidade estigmatizada, que trazia em seu bojo atributos sociais desabonadores, não lhes permitindo outra expectativa de pertencimento senão a uma “identidade desacreditada” ou “desacreditável” (GOFFMAN, 1988).

A maioria deles elaborava suas identidades compartilhando a crença de que pertenciam ao "terceiro sexo", diferente da crença atual, que entende a homossexualidade dentro do quadro de simetria entre pares. A partir de 1965, estabeleceu-se uma disputa pela hegemonia da representação, com a entrada de novos sujeitos na rede e com a ressignificação identitária de antigos participantes.

A rede, por conseguinte, sociabilizava seus membros de acordo com certa visão de mundo, que não era, entretanto, necessariamente compartilhada por todos. Nesse embate, criaram mecanismos para sobrepujar e ressignificar tanto os espaços de sociabilidade que a sociedade lhes reservara quanto suas identidades sexuais.

Através de $O$ Snob e em entrevistas pontuais, foi possível seguir as atuações dos grupos e as mudanças que ocorreram no período estudado. Para isso, atentamos para as demandas e ações da rede, relatadas principalmente em $O$ Snob.

Por conseguinte, acredito que estudar a trajetória peculiar desses grupos, no O Snob, associando-os aos movimentos identitários próprios de sua época, pode contribuir para discutir a história dos direitos individuais, mais especificamente da luta pela igualdade sexual, e para debater a questão da ocupação de espaços gays, a partir das mudanças promovidas nos significados identitários.

Portanto, esse tipo de sociabilidade está diretamente ligado a certa construção social do sujeito e ao local em que a ação se dá. Uma e outro apartados da sociedade maior, embora por ela influenciados. Neste caso, o espaço do sujeito que o constrói é indissociável da própria identidade, com a qual, ao mesmo tempo, se constrói. 
As subculturas sexuais que tinham crescido em áreas urbanas foram campo especialmente fértil para esses experimentos. A abordagem construcionista mostra que essa tentativa de criar novos espaços parcialmente protegidos de elaboração e expressão de novas formas, comportamentos e sensibilidades sexuais, também faz parte de uma luta política mais abrangente para definir a sexualidade. As subculturas não só dão origem a novas maneiras de organizar o comportamento e a identidade, como também a novas formas de oposição e participação simbólica em relação à ordem dominante (VANCE, 1995, p. 16).

Nessa lógica, para entender as ações dos grupos estudados, no que tange à política de afirmação identitária, é fundamental compreender como a sociedade organiza e dá significados a determinadas ações e como esses significados se articulam com as outras maneiras possíveis de organizá-los (dentro de uma subcultura específica). Portanto, é necessário levar em consideração o contexto em que os sujeitos se encontram para que os significados possam ser apreendidos e articulados, e, assim, nos aproximarmos da trajetória empreendida na construção de suas identidades de gênero.

\section{O Snob: o jornal e seus aspectos gráficos e editoriais}

De 1963 a 1969, O Snob totalizou 100 edições, em que se incluem duas extras e uma especial. A distribuição, de início entre amigos, com o passar dos anos ganhou repercussão na “comunidade entendida", informação sobre sua circulação foi encontrada no n. 8, de 1964, que registra a distribuição de 30 exemplares.

De produção doméstica, mimeografado em papel ofício, veiculava fofocas, informações sobre locais de encontros sexuais, notícias de pessoas da rede e parcerias amorosas. Cinema, teatro e poesia também eram alvo de comentários e troças, bem como o que lhe deu origem: ${ }^{6}$ relatos de festas e concursos.

\footnotetext{
${ }^{4}$ Uso essa expressão para sintetizar várias outras encontradas em $O$ Snob, como “mundo entendido” (n. 14/63), “ambiente entendido" (n. 16, 1963), "meios entendidos" (n. 6, 1964) e como contraface do "público fora da comunidade” (n. 4, 1964). Todas essas são empregadas com o mesmo significado de "sociedade bichal” (n. 9, 1963), pois, como veremos adiante, até 1965 “entendido” designava toda a pessoa que "entendesse”, no sentido, de aceitar, valorizar e compartilhar, o modo de vida das "bichas".

${ }^{5}$ A designação "bicha” (ou "boneca”) era uma maneira largamente usada nos meios homossexuais da época para nomear homens que assumiam a posição sexual "passiva” (o que é penetrado) com seu parceiro, o "bofe”, que, por sua vez, era a designação usada para os homens que assumiam a posição "ativa” (o que penetra) nessa relação. A posição de gênero também é importante nessa classificação, na qual, o primeiro estaria no campo feminino (como "terceiro sexo" ou "invertido") e o segundo, no masculino, "homem verdadeiro", que nessa lógica mantinha sua condição heterossexual.

${ }^{6}$ Ver O Snob, n. 1, 1964.
} 
Com periodicidade razoavelmente estável, começou como um pequeno panfleto de duas páginas. Teve periodicidades distintas no decorrer de sua existência. No início, foi um jornal semanal de poucas páginas, passando por um período quinzenal e outro, mensal. A partir do número três, em 1964, circula com capa, na qual eram impressos desenhos de figuras femininas representando pessoas ilustres da rede: “Edméa, é a moça da capa” (Figura 3). É interessante notar como as fotos de capa das revistas da época, com modelos e artistas em poses singulares, eram semelhantes aos desenhos encontrados nas capas de $O$ Snob (Figuras 1 e 2).
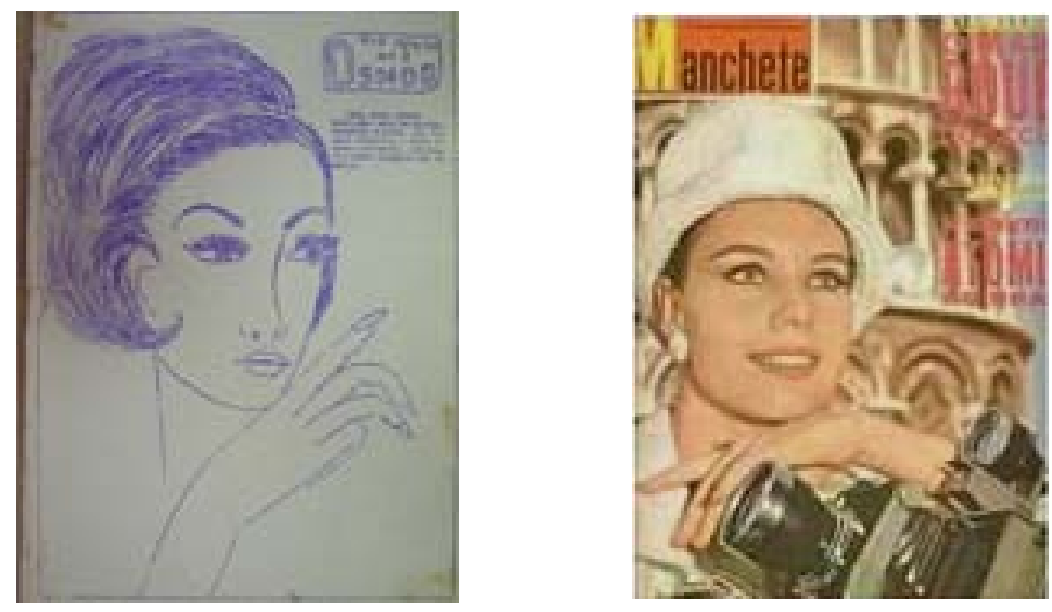

Figuras 1 e 2: capas de O Snob, n. 5, 1964 e Manchete, n. 592, 1963 Fonte:

Suas capas retratavam personagens autodesignadas VIBs (Very important bichas) as VIPs (Very important persons) - da “sociedade bichal”, sempre representadas como mulheres elegantes, em poses delicadas e impostadas. Esses desenhos eram chamados de fotografia, ilusão desmascarada ao primeiro olhar, nossos e deles. Havia, porém, uma cumplicidade tácita para encobrir as duas "inverdades”: não eram fotos, mas desenhos, e não eram mulheres, mas homens. Nessa “ilusão” coletiva, a “verdade” era relativizada. A “comunidade” tinha sua própria noção de realidade ${ }^{7}$ e agia dentro da rede para dar veracidade a suas representações.

Antes de $O$ Snob, pelo menos dois jornais ${ }^{8}$ de temática homossexual circularam na cidade do Rio de Janeiro: $O$ Taradinho, produzido pela Turma $\mathrm{OK}^{9}$ e editado por $\operatorname{Itamar}^{10} \mathrm{em}$

\footnotetext{
${ }^{7}$ Em várias ocasiões, os relatos de $O S n o b$ manifestam que eles vivem um mundo de fantasias.

${ }^{8}$ O Snob, n. 1, 1964.

${ }^{9}$ Um dos grupos que compunham a rede, considerado o primeiro grupo homossexual do Brasil. A Turma OK nasceu a partir de um grupo de convivência, formado, em sua maioria, por homens homossexuais que
} 
1961, ${ }^{11}$ e o Glamour. Ambos se fundiram em 1963, dando origem à A Terceira Força, ${ }^{12}$ que noticiava as atividades da Turma OK.

Diferença importante entre $O$ Snob e A Terceira Força é que o primeiro circulava em circuito público, sendo oferecido em locais de sociabilidade homoerótica; o outro era “privado”, de circulação interna, com o objetivo específico de divulgar notícias relevantes para a Turma OK, em cujas reuniões era lido. Às vezes, exemplar único circulava entre as pessoas.

Em tom de segredo e desabafo, Agildo Guimarães ${ }^{13}$ informa que o nome do jornal foi inspirado por letreiro de loja em uma galeria de antiguidades; nada especial, portanto. Por seu relato, intuo a dissimulação de que fizeram uso para desvincular essa origem banal do requinte que queriam atribuir ao título do jornal, evocando o incomum, em contraposição à visão geral que deles se tinha, como pessoas vulgares e socialmente desajustadas. Investem, portanto, no oposto dessa imagem, provocam de maneira deliberada certo elitismo, sugerindo pessoas especiais e que não se misturavam - literalmente, sujeitos esnobes ${ }^{14}$-, exacerbando o sentimento de superioridade e, ao mesmo tempo, forte ligação com o caráter mundano da existência (moda, festas, elegância, sofisticação, luxo).

Nos primeiros anos, as colunas eram elaboradas pelos vários grupos que compunham a rede; entre 1965 e 1966, começam a se estruturar de maneira diferente, até porque muitas "turmas" se desfizeram, ${ }^{15}$ e se consolidam as colaborações regionais, prestigiadas com colunas fixas.

Nessa linha editorial, destacam-se as colunas regionais, que abordam assuntos referentes às respectivas regiões, em diálogo com a "matriz"; as colunas de fofocas e sociais; as crônicas e contos e, principalmente, a coluna do Pantera, com fofocas "bichais" e “entendidas”, além de histórias fictícias (denominadas série), cujos personagens eram os

mantinham encontros informais no apartamento de um de seus fundadores, Antônio Perez. Considera-se sua data de fundação o dia 13 de janeiro de 1961. No final de 1964, seus membros pararam de reunir-se. Reagrupam-se em 1984, já em outro contexto; em 1985, institucionalizaram-se e montaram sede - ainda hoje em atividade - no Centro da cidade do Rio de Janeiro, constituindo-se como “clube social”. Em 1989, foram criados novo Estatuto e Regulamento Interno sintonizados com os “direitos de livre orientação sexual”.

${ }^{10}$ Um dos fundadores da Turma OK.

${ }^{11}$ O Snob, n. 6, 1964.

12 Interessante o nome, fortemente associado à maneira como seus participantes ressignificam suas condições sexuais a partir da sociedade maior, como "terceiro sexo" (constroem suas identidades sobre expectativas externas, mas as reorganizam à sua maneira).

${ }^{13}$ Entrevista filmada de Agildo Guimarães ao autor. Rio de Janeiro, 12 set. 2009.

${ }^{14}$ Em entrevista ao autor, em 2 set. 2008, Agildo Guimarães desmente essa afirmativa com relação ao Grupo Snob, do qual era líder, mas declara que alguns grupos agiam dessa maneira.

${ }^{15}$ Em O Snob (n. 9, 1964), tem-se a notícia do processo de desestruturação da Turma OK. 
participantes da rede. Pantera introduziu em sua coluna o debate sobre os comportamentos sexuais dos componentes da rede, que hoje pode ser entendido sob a perspectiva das identidades de gênero, a partir de confrontos com outros colunistas e em textos originais versando sobre o cotidiano da rede.

Portanto, ainda que continuem relacionadas aos encontros sociais de vários grupos e às fofocas, encontramos novidades nas colunas, entre elas, sua constante reorganização, tornando-as mais consistentes.

Em 1967 e 1968, O Snob torna-se a arena privilegiada de exposição de divergências de várias ordens, tendo como pano de fundo um modo de expressão sexual distinto do anterior. Essa disputa travada entre participantes, bem como, aliás, entre jornais, iniciada em 1965 com o Pantera, culmina com o estabelecimento de linha editorial bastante diversa da vigente até então e que toma corpo nas edições de 1968.

Em 1967, as colunas de fofocas permanecem, mas surgem outras, de cunho mais cultural, como a que focaliza cinema. As regionais também se mantêm, bem como a do Gato Preto (ex-Pantera), agora intitulada "Bruxarias”. No ano seguinte, uma reestruturação na diretoria reflete-se nas páginas e nos assuntos abordados. Além de colunas sociais sem fofocas, abrem-se espaços (seções e entrevistas) voltados ao debate das condutas sexuais, novas e antigas.

Em seu último ano de circulação, 1969, em março e abril, O Snob mais parece uma revista, com 54 e 60 páginas, respectivamente, com espaço significativo para poesia, contos, crônicas, artigos e comentários sobre cinema. Lança ainda breves diálogos com propósitos de encenação produzidos por participantes do Grupo Snob. Duas ou três colunas sociais e várias páginas são dedicadas a escritos dos componentes do núcleo de outros periódicos. Os editores assim descrevem a nova linha editorial: ${ }^{16}$

1969 parece ser o ano das novidades, pelo menos para nós do SNOB, muita coisa nova acontecerá no decorrer desse ano. Iniciamos com um jornal mais adulto (diário oficial de contos), onde crônicas, poesias, artigos de real interesse, contos e colunismo social sadio, sem fofoquinhas, aliás abandonadas há muito por nossos cronistas, e [suprimidos os] desenhos de figuras femininas indicando rapazes que chegam a dar um ar de gozação, mostrarão nossos propósitos de atingirmos uma realidade do que realmente somos.

\footnotetext{
${ }^{16}$ O Snob, n. 1, 1969.
} 


\section{A rede: o público de $O$ Snob}

Ano de 1963. A cidade do Rio de Janeiro vive clima de efervescência cultural e política que prometia liberdade e ação. Sua imagem continha, para os grupos em estudo, a promessa de se poder viver sem as amarras das cidades menores, ou rurais, possibilitada por mais independência da família e do controle de vizinhanças. O “exílio”, para muitos homossexuais, era condição necessária para construir sua vida em outro cenário cultural, reescrevendo sua biografia. ${ }^{17} \mathrm{O}$ controle social a que o campo ou as cidades pequenas submetem esses atores dificulta sua atuação coletiva, tornando extremamente árduo levar a cabo suas pretensões, sejam de parceria sexual ou de amizades.

Um “sujeito" sempre é produzido pela ordem social que organiza as "experiências" dos indivíduos num dado momento da história [...]. Um "sujeito" sempre é produzido em e pela "subordinação" a uma ordem, a regras, normas, leis... Isto é verdade para todos os "sujeitos". Ser "sujeito" e estar subordinado a um sistema de constrangimentos são uma única e mesma coisa. Mas é ainda mais para os "sujeitos" aos quais num lugar “inferiorizado" é atribuído pela ordem social e sexual, como é o caso dos homossexuais (ERIBON, 2008, p. 16)

Eribon sugere que a construção identitária em uma estrutura heterocentrada, na qual a imagem do "homossexual” se faz por intermédio da "injúria”, 18 irá impregnar as relações interpessoais e subjetivas dos sujeitos que sofrem esse tipo de tratamento. Segundo o autor, a “injúria” a que os gays estão submetidos os subordina a certas normas de atuação e de ocupação de território, mas não sem resistência. De fato, aponta, a ordem sexual que os sujeita também possibilita criar modos de vida e espaços de liberdade, que variarão em cada época, ou seja, as formas de resistência à dominação não são únicas nem tampouco universais, mas produto do cenário que os envolve em função do tempo e do espaço.

O problema da “injúria”, portanto, será absorvido e negociado de maneira diferente no tempo e no espaço, podendo produzir ações diferentes para sua convivência ou resistência a ele. O autor trabalha com dois conceitos analíticos (goffmanianos) de identidade que se inter-relacionam: a identidade atribuída pela sociedade (o que é esperado) e a identidade pessoal, realizada a partir da primeira, possibilitando reinventar-se, “o que significa, por

\footnotetext{
${ }^{17}$ Ver Goffman (1988, p. 73).

18 “A injúria é um enunciado performático: ela tem por função produzir efeitos e principalmente instituir, ou perpetuar, o corte entre os 'normais' e aqueles que Goffman chama de 'estigmatizados', fazendo esse corte entrar na cabeça dos indivíduos. A injúria me diz o que sou na medida em que me faz o que sou” (ERIBON, 2008, p. 29).
} 
conseguinte, que o ato pelo qual a identidade é reinventada sempre é dependente da identidade tal qual é imposta pela ordem sexual” (ERIBON, 2008, p. 17).

Esta possibilidade de reconstrução identitária é favorecida pelo modo de vida da metrópole, pois a dominação a que são submetidos nas cidades menores diminui a possibilidade de uma vida associativa. Isso não quer dizer que eles não sejam perseguidos nos grandes centros. Os grandes centros, todavia, comportam estratégias que propiciam aos sujeitos estabelecer-se de maneira mais fluida e com maior margem de negociação com a sociedade. Uma dessas estratégias é o anonimato (que possibilita uma vida dupla), que, no caso em estudo, possibilitou construir espaços de sociabilidade à parte da sociedade estabelecida - o "gueto".

Segundo Eribon (2008, p. 31), são estas condições que fazem com que os “homossexuais” sejam atraídos pela cidade e suas redes de sociabilidade: “São muitos os que procuram deixar o lugar onde nasceram e onde passaram a infância para vir se instalar em cidades mais acolhedoras [...] Esse movimento de fuga seguramente conduz os homossexuais para a cidade grande.” No caso em estudo, essa estratégia de busca do anonimato nas grandes cidades também comportou mudanças de bairros ou, então, criação de laços de amizade longe dos olhos vigilantes de vizinhos e familiares.

Os participantes da rede provinham de vários grupos (ou turmas) que se formaram, à época, principalmente por afinidades regionais e/ou injunções sociais que os levavam ao “isolamento” em relação à sociedade maior. Dessa maneira, desenvolveram uma forma de sociabilidade que teve como característica peculiar produzir encontros em residências de alguns dos participantes, promovendo festas, concursos, peças teatrais, jantares e pequenos encontros informais, o que levou à formação de sólidos laços de solidariedade. Essa rede de sociabilidade era fortemente endógena. Estimulava estratégias de conhecimento pessoal pelo acolhimento num grupo de interessados em estabelecer amizade ou encontros sexuais com um dos participantes, com abertura para grupos externos nas grandes festas que promoviam. Isto não quer dizer que todas essas relações só se passassem dentro dos grupos formados nessa rede, embora houvesse certo constrangimento para que se dessem sob a "supervisão" do grupo de origem e fossem divulgadas para a rede por meio do jornal.

A rede de sociabilidade focalizada incorporava esses sujeitos em “fuga”, compondo vários grupos em que criaram laços de amizade que remontam ao final dos anos 50. O relato de dois participantes ${ }^{19}$ da rede exemplifica o movimento de "fuga” empreendido em busca do

\footnotetext{
${ }^{19}$ Entrevistas concedidas ao autor por Agildo Guimarães, em 9 fev. 2008, e por Jair (nome fictício) em 23 nov. 2009, ambas no Rio de Janeiro.
} 
anonimato, para experimentar novos cenários culturais sem a influência familiar e a vigilância vicinal:

As pessoas não imaginam o que era naquela época sair da sua cidade e vir para o Rio. O Rio de Janeiro era como se fosse a redenção. A gente achava que vinha para o Rio, e seria tudo melhor, e em parte era; lá era uma perseguição muito pior do que no Rio, porque a gente não podia fazer nada (AG).

No Rio de Janeiro eu podia crescer, me soltar, me conhecer melhor, não tinha muito claro estas ideias [...] o que eu tinha muito claro é que numa cidade pequena eu estaria condenado a ter que me casar logo [...] para salvar as aparências. Eu ia ser muito infeliz. No Rio de Janeiro, na cidade grande... A ideia do anonimato de uma cidade grande me atraia muito. No anonimato total, saber que poderia aprontar alguma, ninguém... Fazer o que quisesse, ser um anônimo na multidão era o maior atrativo (J).

Contabilizei nove grupos nos dois primeiros anos de atuação do jornal O Snob (19631964), que assim se designavam: Turma do Catete, Turma de Copacabana, Turma da Zona Norte, Turma do Leme, Turma OK, Turma da Glória, Turma da Mafalda, Turma de Botafogo e o Grupo Snob.

As reuniões, segundo Agildo Guimarães, ${ }^{20}$ eram “mais para se conversar, para se encontrar, conversar, rir. Cada um levava algo para comer. Lógico que sempre tinha um bofe. Acho que era importante o prazer visual de ver um bofe bonito”. Esse relato parece-me fundamental para entender a construção desses grupos, cujos participantes, vivendo em uma grande cidade, eram agredidos e isolados socialmente em função de seu comportamento sociossexual, que na maioria das vezes precisavam manter em segredo. Para superar essa maneira de viver característica dos anos 60, quando não podiam ser “eles mesmos”, procuravam promover agregação social com objetivo de “existir”.

O domicílio foi o local privilegiado por esses grupos para suas reuniões, posto que nesse espaço conseguiam filtrar e controlar a frequência. Esses encontros tinham seu ápice nas “festas temáticas”, que envolviam planejamento e produção, demandando vários encontros precedentes para escolher o tema, angariar recursos e montar estratégias para sua realização. Essas “festas temáticas” poderiam comportar concursos de misses e de Os melhores do ano, shows, teatros, jantares, configurando-se, assim, em poderosos agentes de sociabilidade. Essas atividades foram tão importantes que se tornou necessário criar um jornal, $O$ Snob, que teve em seu início a tarefa de relatar esses encontros especiais, mas que

\footnotetext{
${ }^{20}$ Entrevista de Agildo Guimarães ao autor. Rio de Janeiro, 29 jul. 2007.
} 
logo começou a divulgar também outras notícias de interesse da rede, como, por exemplo, os arranjos de parceria afetivos e/ou sexuais e suas atividades culturais.

Os grupos eram fortemente influenciados pela sociedade maior, havendo de fato a tentativa de reproduzir o que era a "alta sociedade” carioca, promovendo em suas festas atmosfera $^{21}$ de "sofisticação" semelhante à desse segmento social, cujos valores apreendiam de longe, embora adequando-os a suas limitações financeiras. Neste contexto, as reuniões em residências, ao mesmo tempo que protegiam e facilitavam seus encontros de amizade e sexoafetivos, produziam, também, uma espécie de sociabilidade fortemente associada ao “estigma do passivo”. ${ }^{22}$ Para superar essa circunstância, promoviam a valorização das ações das "bichas”, enfatizando seu poder de ação e organização.

Nos relatos do jornal $O S n o b$, em que se dão os nomes dos participantes da rede, contabilizei 173 sujeitos nas edições de 1963; identifiquei a região de origem de 38 (22\% do total). Destes, 89\% não eram naturais da cidade do Rio de Janeiro.

Em 1964 aumenta o afluxo de pessoas nas atividades da rede: 375, entre "bichas” e "bofes”. Desse total, foi possível identificar a região de origem de 86 participantes (22\% do total), o que apontou 95\% não-cariocas.

Esses números podem nos indicar uma "fuga” de suas origens regionais em busca de vida mais satisfatória, com o propósito provável de alcançar mais liberdade de atuação no que tange à sexualidade. Essa população, em todo o período estudado, busca lugares em que se possa expressar. Até 1965, os grupos que compunham a rede não encontravam lugares exclusivamente homossexuais. ${ }^{23}$ A procura de aproximação de seus "iguais” os leva à cidade grande, sonhando com a realização das promessas de vivenciar algo diferente da repressão imposta em seu local de origem (familiar e/ou regional); leva-os a encontrar "zonas morais" em que possam expressar suas demandas afetivas e/ou sexuais, criar lugares de encontro ou de sociabilidade.

A ocupação profissional dos participantes dessa rede relatada em $O$ Snob - "bichas", "bofes" e três mulheres (ao que tudo indica heterossexuais) - embora fracamente identificada, aparentemente era de pouca relevância para a aceitação na rede. Desse universo, apenas 17\% em 1963 e 7\% em 1964 aparecem no jornal correlacionados à sua atividade profissional, cuja menção, em geral, se relacionava a eventual contribuição com o grupo. Identifiquei esses profissionais num contexto de prestação de serviço ao grupo (por exemplo, confecção ou

\footnotetext{
${ }^{21}$ Uma mistura de deboche e admiração pela alta sociedade carioca.

${ }^{22}$ Ver Misse, 1979.

${ }^{23}$ Há vários relatos em O Snob (1963) de apenas um local exclusivo, o “Banzai”, em Juiz de Fora. No Rio de Janeiro, essa exclusividade só era alcançada pelos grupos nas reuniões e festas em residências.
} 
venda de roupas para os participantes, greve dos bancários e possibilidade de desemprego, decorações nos apartamentos e atividades artísticas que um indivíduo desenvolvia no grupo ou sua valorização fora do grupo) ou que justificaria ausências e preocupações.

Quanto à distribuição dessa população entre “bichas” e "bofes”, foram utilizados dados encontrados nos exemplares do jornal de 63 e 64. Em 1963, 49\% dos 173 participantes eram relatados como "bichas” (ou "bonecas”), e 32\%, como “bofes”. Dos 374 de 1964, 55\% foram identificados como "bichas", e 26\%, como "bofes”. Dos $17 \%$ restantes ${ }^{24}$ em cada ano, não foi possível distinguir com clareza a "identidade de sexo", ${ }^{25}$ embora, na maioria das vezes, os depoimentos se assemelhem mais com o das "bichas”. Geralmente os "bofes” aparecem no jornal em função de seu relacionamento com uma "bicha”, como, por exemplo, o "Willian da Tatiana"; ${ }^{26}$ ou nas colunas "Eles os bofes", ou "Falando deles”. Os não classificados foram quase sempre citados no jornal individualmente, como as "bichas" que identifiquei. Se assim for, os "bofes” configuravam produto escasso e, por isso, valorizado.

Percebo, também, a partir da leitura de $O S n o b$, uma população flutuante, do tipo que Guimarães (2004) e Silva (2005 [1957]) reportam em suas pesquisas como network atomizada. No entanto, os grupos aqui estudados tinham também personagens marcantes e público fiel a suas atividades, que consolidavam objetivos singulares (modo de agir, gostos) e lhes garantiam visão de mundo própria - eram, portanto, mais do que um “coletivo”. Uma parte substancial estabeleceu laços afetivos e/ou sexuais duradouros e de reconhecimento nominal dentro da rede. Dos participantes que encontramos mencionados em 1963 e 1964, pelo menos 127 tinham marcada assiduidade nos relatos do jornal.

Essa aproximação possibilitou, a meu ver, modo de vida peculiar, consolidando uma ação cultural própria, seja nas atividades festivas em que expressavam sua visão de mundo ou por sua crença identitária, conformando-os em uma "subcultura", posto que havia um sentimento de pertencimento àquele espaço social que construíram e a suas manifestações sociossexuais.

Até 1964, cada grupo compunha seu próprio esquema para “arregimentar” seus componentes, o que significava estreitar ou estabelecer laços de amizade.

\footnotetext{
${ }^{24}$ Mulheres constituíam 2\%.

${ }^{25}$ A identidade de sexo é reconhecida pela associação entre o sexo biológico (macho X fêmea) e os atributos de gênero (masculino X feminino), associados àquele por uma dada cultura (CÂMARA, 2002, p. 59).

${ }^{26}$ Tatiana é pseudônimo de um dos participantes da rede, que, como quase todas as "bichas", escolhera um nome no feminino e assim era tratado.
} 
Na Turma OK, havia hierarquia informal, liderança e divisão de tarefas. Seu jornal, $A$ terceira força, servia como elo entre os participantes, informando sua “programação” e os interesses de seus componentes.

Na Turma da Zona Norte, esta integração se dava em seus bairros de origem. Longe do burburinho da Zona Sul, mas em contato permanente, estabeleciam seus encontros nas casas de seus participantes e nos bares locais, informando seus membros sobre as atividades e interesses por meio do jornal O Vagalume (antigo Zona Norte).

Nos grupos da Zona Sul, as atividades giravam em torno das casas que promoviam a maioria das festas relatadas em $O$ Snob. Por fim, temos o Grupo Snob, que produzia o jornal O Snob, ponto de integração de todos os grupos, promovendo sua maior aproximação. Seus participantes também pertenciam a outros grupos, como Agildo Guimarães, o editor, que fazia parte da Turma OK.

No "exílio" da terra de origem e/ou familiar, os amigos tornam-se uma "família substituta”. Não podendo compartilhar suas apreensões e desejos com os parentes de origem, constroem com os amigos relações de afeto e confiança.

Ainda que fracamente, observei, como maneira peculiar de entrada nos grupos, a “adoção” do novato na “comunidade entendida”, utilizando a nomeação tradicional da família estendida: “filho”, “filha”, “sobrinha”, “madrinha”, “mãe”.

À “mãe” cabia a obrigação de introduzir o pupilo junto aos meandros desse "outro mundo”, de maneira que não infringisse as regras estabelecidas, soubesse aproveitar as oportunidades ofertadas pela rede e aprendesse a se portar e a conduzir suas aptidões. Não se esclareceu, contudo, se havia interesse sexual na adoção de um "filho”, mas tudo indica que $\operatorname{sim}$.

A grande atração que sem dúvida esses grupos exerciam sobre os indivíduos, em todo o período estudado, diz respeito às afinidades que os ligavam, primordialmente, às conformações identitárias e aos interesses que compartilhavam: literatura, cinema, teatro, concursos de misses, elegância na vestimenta, condições de vida, afastamento da família e/ou da terra natal e conquista de espaços de convivência em que se pudessem expressar. A partir de 1965, os “entendidos” ${ }^{27}$ também estão incluídos nesse cenário, o que os conformava a um espaço de atuação à parte da sociedade maior, mas sem com ela perder o vínculo.

\footnotetext{
27 Como a categoria “entendido” está em disputa de representação dentro da rede, podendo significar a comunidade ou uma ação identitária, é importante observar, num dado relato do jornal, seu sentido, pois, a partir de 1965, ela tem trajetória pendular, ora identificando todos os componentes da rede, ora, como neste caso, só aqueles que não mais seguem os "roteiros sexuais” (GAGNON, 2006) tradicionais que os separem em "bicha” e "bofe”; adotam outra conduta, mais igualitária, que se dá na base da orientação sexual (interessa a direção do
} 
Essas injunções possibilitaram e reforçaram seus laços e moldaram a maneira de atuar na rede fortalecedora das identidades específicas através da regulação das normas que possibilitaram sua existência.

As relações entre os vários participantes dessa rede de sociabilidade envolveram, todavia, também vários conflitos relacionados a modos de se comportar, se vestir, se expressar e manter as parcerias amorosas. A atualização desses padrões de procedimento era muitas vezes explicitada por meio da fofoca.

Com a lenta desarticulação dessas turmas, ao longo de 1965 e 1966, novos grupos vão sendo criados a partir dos componentes dispersos: são aqueles formados em torno dos jornais que florescem nesses anos, muito influenciados pelo sucesso de $O$ Snob.

Nesse período, a rede carioca vai-se consolidando em volta de seus respectivos jornais e construindo, com a acolhida de outros personagens, novos experimentos identitários. O Grupo Snob amplia sua rede de sociabilidade para além da cidade do Rio de Janeiro, fazendo contato permanente, através dos jornais e das viagens, com outras cidades do estado e outras espalhadas pelas regiões do Brasil, mas tendo sempre como ponto central o grupo que produz e sustenta $O S n o b$.

Os principais atores do período 1963-1964 continuam, em sua maioria, atuando na elaboração do jornal, mas em 1965-1966 são incorporados outros. Alguns começam a questionar a função do periódico e seu modo de retratar os participantes da rede, gerando conflitos internos, que são expostos em suas colunas, disputa sempre mediada pelo idealizador e principal realizador do jornal, Agildo Guimarães.

Esta nova dinâmica de agrupamento tem uma peculiaridade: os jornais e seus “associados” formam um grupo que vai além de seus editores e redatores. Trata-se de um jornal/grupo que não se limita a seus realizadores, incluindo um rol de pessoas com ligações afetivas e classificadas snobianas. Outros jornais domésticos, ao que tudo indica, seguiram a mesma trajetória (jornal/grupo) e foram produzidos com a mesma temática.

Em 1966, circulavam (com maior ou menor permanência e periodicidade), no estado do Rio de Janeiro: Subúrbio à Noite (Zona Norte), O Mito (Niterói), O Cacho (Niterói), O Estábulo, Le Sophistiqué (Campos), Newsbook (antigo A Terceira Força). Em 1967, mais cinco são citados em O Snob: Os Felinos (Niterói), O Centro, O Grupo, O Núcleo, Vinte de Abril e Cinelândia à Noite. Em 1968, estão em atividade no estado do Rio de Janeiro os

desejo sexual - se voltado para o mesmo sexo ou não -, classificando-os como homossexuais ou heterossexuais, respectivamente). Esse tema será desenvolvido adiante. 
seguintes jornais: O Snob, Darling, O Centro, O Centauro, La Saison, Subúrbio à Noite, O Vic, O Estábulo, Le Femme, O Star, Opinião e O Mito.

Outra novidade é a emergência de dois subgrupos, o Club $10^{28}$ e Os Pelicanos. ${ }^{29}$ Eles são peculiares e, no meu entender, reflexo dos questionamentos que parte dos novos componentes impõe ao grupo. Todos os membros desses dois pequenos grupos participavam ativamente de $O$ Snob, mas sentiram necessidade de se diferenciar a partir dos "roteiros sexuais” (GAGNON, 2006) que os orientavam; o Club10 era exclusivamente de "bonecas” e Os Pelicanos, formados apenas por "entendidos”.

Deixaram de circular em 1967: O Vagalume (Bangu), O Chic (Copacabana), O Queridinho (Copacabana), O Charme (Botafogo), A Terceira Força (Turma OK), Le Carrilon (Tijuca), Le Sophistiqué (Campos) - todos, ao que tudo indica, das antigas turmas cujos interesses divulgavam.

Essa proliferação de jornais/grupos, porém, não foi pacífica. Deu-se em meio a fofocas e autopromoções. Estabelece-se a luta por prestígio. Os desacordos quanto às condutas sexuais dos participantes eram exacerbados nas maledicências cotidianas. A “paz” é selada entre os jornais/grupos em 1969, com a entrada de $O$ Snob na Associação Brasileira de Imprensa Gay - Abig -, criada em 1968, cuja diretoria passou então a estabelecer critérios éticos na produção dos jornais a ela associados.

No período estudado, o “exílio” continua sendo para esses atores uma forma de se livrarem do jugo familiar e de vizinhança. Por conseguinte, o afluxo de pessoas de outras regiões permanece; a acolhida dos grupos ainda é um atrativo para elas. O contexto profissional pouca influência exerce sobre sua entrada, interessando mais a situação de conflito com as normas sexuais da sociedade maior. A aceitação, porém, não era irrestrita. Era primordial a submissão a algumas normas estabelecidas pela rede, como demonstra uma das colunistas, fazendo retrospectiva dos três anos de circulação do jornal:

O Snob deixou de ser um clã fechado e restrito para tornar-se uma grande sociedade. São "snobs" todos aqueles que queiram se equilibrar dentro de certo gabarito que é norteado pelo jornal onde as pessoas se encontram se conhecem e trocam impressões sobre qualquer assunto e passam a existir num clima [ilegível] que dá manchetes e promoções a pequenos acontecimentos importantes na nossa vida alienados dos problemas humanos cognominados de "normais" nesta civilização que caminha vertiginosamente para um paroxismo (O SNOB, n. 11, 1965).

\section{O Snob: seu conteúdo e seus propósitos}

\footnotetext{
${ }^{28}$ O Snob, n.21, 1965.

${ }^{29}$ O Snob, n.11, 1966.
} 
Este jornal influenciou de maneira marcante os indivíduos envolvidos na rede, ao relatar as maneiras e os modos de atuar de seus participantes, indicando o que a "comunidade" considerava relevante em determinado momento, informando sobre comportamentos adequados, valorizando suas atuações e controlando a formação de casais. Muitas vezes, as críticas eram severas, usando de ironia e humor. Valorizava as relações endógenas como a forma mais adequada para a formação de casais, prática que controlava pela "exigência” de que os parceiros fossem oficialmente apresentados ao grupo de origem e/ou divulgados para a rede via jornal, havendo, ainda que não declarada, uma "supervisão" de seus integrantes, o que favorecia certa proteção contra a violência externa.

Outra estratégia para minorar os riscos das relações extrarrede foi divulgar as zonas de "pegação"30 e seus perigos por meio da coluna "Da arte de caçar”. O veículo mais eficiente, contudo, ainda era a fofoca. As colunistas intimidavam as "bichas" “casadas" relatando suas “escapadas”, os vexames que porventura qualquer "bicha” vivenciasse nos encontros casuais, os roubos sofridos, os pagamentos por relações sexuais, envergonhando-as por desqualificar suas habilidades de “caçadoras”. Também controlavam as relações internas, sinalizando trocas de casais e a solidão de alguns membros e repreendendo os "desvios” identitários de outros. $^{31}$

Tudo isso demonstra o forte controle que a rede exercia nas atuações de parceria de seus membros, o que, entretanto, não impediu comportamentos pontuais ou, melhor, atuações “desviantes” no interior de seu próprio universo, que aconteciam à revelia do que a rede preconizava como relações sexo-afetivas entre homens, abrindo espaço para a possibilidade de novos arranjos sociossexuais.

Na coluna "Da arte de caçar”, o jornal também “ensinava” como e onde arrumar parceiro com fim sexual. Informava locais e perigos que envolvia essa incursão e as "manhas” para abordar alguém potencialmente afeito ao intercurso sexual com indivíduos do mesmo sexo.

\footnotetext{
30 "Pegação" é termo que tem para o grupo significado relacionado tanto ao ato quanto ao local. Em local de “pegação” há “permissão” para exprimir com mais objetividade a intenção sexual das ações ali praticadas. É onde se "caça”, e o "caçador", no caso, é a "bicha” que "pega o bofe”, metáfora imediatamente associada a objeto exposto e acessível para ser usado sexualmente, o que denota relação sem apego afetivo, encontro casual. Exemplo exacerbado da transformação do "bofe” em objeto foi sua colocação como um dos itens a serem arrematados em leilão promovido numa reunião que visava angariar dinheiro para um concurso de miss que pretendiam promover.

${ }^{31}$ Sobre as atuações “desviantes” e suas consequências dentro da rede, ver COSTA, 2010, p. 96.
} 
Cabe, no entanto, observar que na maioria das vezes a opinião do jornal valorizava o “casamento”, mas, posto que a "pegação” fazia parte do modo de vida de seus participantes, abria espaço em suas páginas para essa “tendência”, muitas vezes, depreciando-a:

No capítulo anterior, focalizamos a praia. Hoje o assunto é futebol [...] Se você não fez a conquista desejada na praia [...] o dia não está perdido. Aproveite a tarde e vá ao Maracanã [...]

Máxima discrição ao agir no estádio; o mínimo de pinta que você deixar transparecer poderá ocasionar o massacre de sua frágil figurinha.

Tudo o que você tem a fazer é postar-se nos banheiros do estádio [...] É um expediente baixo que muitas não adotarão (eu também não adoto), mas é o mais prudente.

[Quando o jogo começa] até o policiamento vai para o estádio assistir a partida [...]

Tudo [sic] que não estiver assistindo ou é "bofe”, ou é "tia”. Afaste-se das "tias", aproxime-se dos "bofes", faça suas abordagens e fique a vontade, porque a tarde é sua, minha CARA LEITORA (O SNOB, n. 9, 1964).

Nos dois primeiros anos de existência, os valores que a rede constituiu eram explicitados visando ao fortalecimento da autoestima, à transformação de espaços e ao controle das atuações dos “atores” envolvidos na rede de sociabilidade. Em 1965, a coluna do Pantera propôs, em sua estréia, a discussão do "homossexualismo". ${ }^{32}$ Neste momento aparecem discordâncias quanto às atuações tanto no nível jornalístico quanto no ideológico.

Esta discussão vai-se estender ao longo de 1966 e 1967. Gato Preto consolida a temática lançando a série: "Homossexualismo, esse desconhecido”33 (depois de anunciá-la um ano antes, ainda como Pantera), relatando a história de dois meninos que se relacionaram sexualmente no colégio interno e anos depois, já homens, casualmente se encontram. O que fora "passivo" na relação juvenil era heterossexual e estava casado e bem ajustado nessa condição; o que fora "ativo” tornara-se homossexual. Com base nessa história, questiona as condutas sexuais, comportamentos sexuais e os papéis de gênero dos membros da rede.

Assim, pouco a pouco, a ideia de discutir a "homossexualidade" no jornal foi se consolidando. Espaços significativos foram abertos para o debate e esclarecimento acerca do assunto: transcrições de textos jornalísticos sobre o tema, crônicas e contos também foram reproduzidos dos jornais de grande circulação do Rio de Janeiro.

Em 1967, toma força a discussão sobre a função do jornal, com a seguinte proposta de Os Pelicanos, ${ }^{34}$ apoiada por Gilka (Agildo Guimarães):

\footnotetext{
${ }^{32}$ A escolha desse termo decorre dos relatos do jornal.

${ }^{33}$ O Snob, n. 3, 1966. A promessa de transformar o assunto em série não se concretiza.

${ }^{34}$ O Snob, n. 12, 1967.
} 
O jornalismo entendido deve ser feito para o esclarecimento das pessoas, mesmo os homossexuais, a respeito do homossexualismo. Pouquíssimas pessoas, mesmo os leitores do Snob, conseguem debater este tema com respeito, conhecimento e seriedade.

As colunas assinadas que nos tragam depoimentos honestos de pessoas entendidas; sobram colunas que nos trazem fofocas, escritas por pessoas que não sabem realmente o que é homossexualismo, do qual só [ilegível] a prática. Ressalta-se que as honrosas exceções confirmam a regra.

Se algum dia chegasse a diretor desse jornal, procuraria [ilegível] apresentando inteligentes páginas sobre o homossexualismo, trabalhos de pesquisa, estatísticas, comentários sobre artes e outros trabalhos que trouxessem realmente cultura e esclarecimento. Enquanto não chega esse dia, vou lendo atentamente o Snob, que ainda é o expoente máximo da imprensa entendida.

A partir de 1968, mais uma reestruturação se verifica na linha editorial de $O$ Snob, para contemplar os novos assuntos. Em contraposição a outros jornais, repudia as fofocas (muito importantes na primeira fase, até 1965), publicando-as raramente. Gilka abdica da direção, tornando-se presidente de honra e abre o primeiro número de 1968 com editorial em que expõe o objetivo do jornal, ligando-o ao “ideal recreativo e literário” e em sintonia com novos pensamentos e ideias trazidos pelos componentes mais novos.

De maneira geral, os "bofes” (os “maridos de nossa sociedade”), em contraposição aos “entendidos”, gravitavam como satélites em torno das “bichas”. Em 1968, porém, ganham "voz” no jornal, em nova coluna de entrevista "Eles têm a palavra”. ${ }^{35}$ Também nesse ano, a direção de Subúrbio à Noite é assumida por um "bofe”, ${ }^{36}$ o que, segundo os relatos de $O$ Snob, gerou controvérsias entre algumas "bichas", apesar de mantida a mesma linha editorial: um jornal para e sobre as "bichas".

O embate identitário vai ganhando força. Mudanças na linha editorial introduzidas em 1968 vêm em etapas: nos primeiros três números, a coluna do Gato Preto passa a ser recreativa, com raras oportunidades de trocas de ideias. Nota-se, com isso, "silêncio” também em relação às “novas identidades”. Por outro lado, é veemente a crítica à guerra por prestígio desencadeada entre os componentes. Nessa "guerra de vaidades”, o assunto dos "entendidos" jogava mais "lenha na fogueira”, cujo estopim se instalava nas acusações de que esses eram "falsos bofes".

Ainda nesse primeiro semestre, porém, reeditam "Bruxarias", ${ }^{37}$ em que Gato Preto tem mais espaço para expor seus argumentos. No segundo semestre, é lançada mais uma

\footnotetext{
${ }^{35}$ O Snob, n. 2, 1968.

${ }^{36}$ Frank Casparelli, “casado” com Christine Casparelli, que também fazia parte da diretoria.

${ }^{37}$ O Snob, n. 4, 1968.
} 
coluna, que se adequava à noção hegemônica de conformação de casal entre "bicha/mulher” e "bofe/homem”: "Diário de uma mulher casada”. 38

No segundo semestre, o jornal começa, de maneira mais contundente, a debater a questão das identidades em disputa. Notórios componentes da rede desde antes de 1963 e colaboradores desde o nascedouro do jornal, que se haviam afastado de sua elaboração no início de 1968, embora continuassem a atuar no grupo, tornam-se então notícia ${ }^{39}$ :

K. Offenbach mais Ceeme prometeram voltar às páginas d'O SNOB caso ele continue apresentando algo mais elevado do que notinhas de mulherzinha [...] e ainda acrescentou que homossexualismo tem um campo tão vasto e interessante a ser explorado para perdermos tempo em algo ultrapassado e sujo.

Em 1969, os editores lançam colunas que consideram de "real interesse” para a rede, contemplando-as com poesias que tomaram três páginas. Paralelamente, as colunas estaduais ou municipais ficaram reduzidas às de Salvador e Manaus. Mais de 15 páginas foram dedicadas a contos e crônicas, com a participação de outros jornais, tentando maior integração com a rede. Adiante se explicitam os propósitos do jornal e como seus membros pretendem ser compreendidos: ${ }^{40}$

[...] assuntos diversos que interessam os HOMÓFILOS. A fase é de politizar culturalmente.

[...] o que nos leva a todos nessa projeção é um ideal comum de humanos a humanos mostrar que nos insurgimos contra uma marginalização que procuram nos impor que o homossexualismo seja apenas uma fome escusa e degradante de vielas noturnas, ou de luzes coloridas sob o burlesco fantasioso dos palcos de teatros onde alguns travestidos lantejoulam sua realidade, ou de um comportamento sexual exótico, ou ainda uma passividade mórbida.

Talvez a natureza não nos tenha dado uma opção, mas a vida nos oferece uma atitude de escolha e podemos numa catarse romper esses liames que nos sufoca e assumir na vida um comportamento lúcido e descontraído evoluindo num sentido positivo e racional do que realmente somos, do que pretendemos.

O grupo Snob também passa a se preocupar com a imagem que transmite aos "de fora”. Parte de seus membros não quer ser "representada” nem como pessoas exóticas ou

\footnotetext{
${ }^{38}$ Id., n. 7, 1968.

${ }^{39}$ Id., n. 4, 1968.

${ }^{40}$ Id., n. 1, 1969.
} 
marginais, nem por afeminados, e percebe que suas atuações serão ridicularizadas na sociedade maior enquanto preservarem essas condutas. ${ }^{41}$ "O SNOB vai ser uma revista homossexual e humana [...] garantimos que em pouco tempo quando um leigo no assunto pegar em nossas folhas não será preciso aderir para ver que existem pessoas que não querem debochar da sociedade, mas querem ser aceitos e compreendidos.”

O primeiro passo foi dado pelo grupo de $O$ Snob quando se abriu ao debate sobre as nominações no feminino, ${ }^{42}$ fazendo com que parte do grupo reavaliasse seu posicionamento, "rebatizando-se" com nomes masculinos. Gato Preto justifica essa atitude pensando na visibilidade e aceitação externas ${ }^{43}$, imaginando uma futura organização para "quem sabe lutar pelos nossos direitos junto à sociedade... e de saída não é com nome de Mariazinha de Souza que conseguiremos". 44

Imbuídos desse pensamento, os editores de $O S n o b$, em sua última edição, estampam na capa, em vez das tradicionais figuras femininas, o desenho de dois rapazes nus, deitados, se beijando (Figura 4). Vários argumentos justificam essa capa; o primeiro, defendia a ideia de que as figuras passadas não os representavam em sua totalidade ${ }^{45}$, nem constituíam o tipo de imagem que desejam passar. O segundo, observava que é mais agradável para um "homossexual” apreciar um corpo masculino do que mulheres em poses.
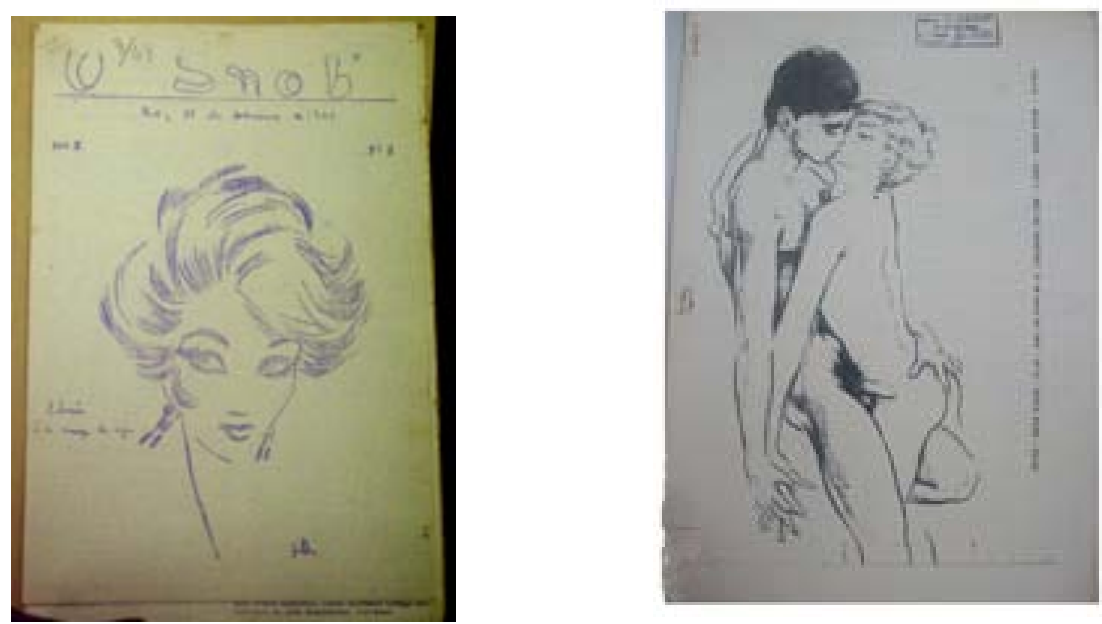

Figuras 3 e 4: Primeira e última capa de $O$ Snob, n.3, 1964 e n.2, 1969, respectivamente

\footnotetext{
${ }^{41}$ O Snob, n. 2, 1969.

${ }^{42}$ Sobre esse debate, ver COSTA, 2010, p. 57

${ }^{43}$ Outro exemplo dessa preocupação é expresso no seguinte relato: "quando um jornal entendido cai em mãos de pessoas fora do 'nosso mundo', elas gostam... dão grandes gargalhadas, mas fica tudo no deboche. Falamos mal da sociedade, mas qual sociedade vai aceitar pessoas que cismam em dizer que são Marias? E nós no lugar de lutar buscando respeito, propagamos em nossos jornais muito mais o nosso lado negativo do que as virtudes imensas que cada um tem dentro de si” (O SNOB, n. 2, 1969).

${ }^{44}$ O Snob, n. 2, 1969.

45 “Se o homossexualismo fosse só frescura, ótimo... mas também está provado que as pintosas é a minoria, mas parecem ser numerosas exatamente por se tornarem caricaturas e chamarem atenções diversas” ( $O S N O B$, n. 2, 1969).
} 


\section{A "Comunidade entendida", segundo O Snob}

Green (1999, p. 324) localiza a expressão “entendido” em cartas trocadas entre homossexuais na década de 1940, observando que a usavam como código, com o intuito de confundir um leitor não autorizado. No entanto, o autor observa que a "maioria dos antropólogos que escreve sobre homossexualidade no Brasil data o uso do termo em 1960”.

Guimarães (2004) compreende o “entendido” como aquele homossexual que, diferentemente da "bicha”, busca igualdade entre os parceiros com relação aos papéis sexuais. Perde importância a questão do "passivo/ativo" que os qualificaria como "bicha” ou "bofe”. Também para MacRae (1990), os “entendidos” não reproduzem essa díade ${ }^{46}$ e adotam comportamento sexual mais igualitário, análogo ao do gay, embora dessa categoria se distanciem pelo menor grau de visibilidade que propõem dar à sua identidade.

Desde sua criação, o jornal $O$ Snob apresentava os arranjos sociais de seus participantes como uma “comunidade entendida” (ou "sociedade bichal”). Essa “comunidade” envolvia todos os indivíduos que participavam ativamente dos encontros e que se adequassem às referências e aos interesses das "bichas"; desse ponto de vista, aliás, "elas" não tinham nada de passivas. Articulavam suas parcerias e movimentavam a "sociedade bichal" produzindo as festas, fornecendo as casas para os encontros, escolhendo os "bofes”, criando, assim, as regras de convivência. Pelo que pude perceber nos relatos do jornal, essa “comunidade” era composta por “entendidos”, assim designados independente de posição assumida no ato sexual ou dos papéis de gênero estabelecidos, fossem "bichas", "bofes” ou mesmo as três mulheres (heterossexuais) que participavam da rede, pois valorizavam o modo de vida "bichal".

Exemplo desse roteiro está impresso nos tipos de prêmio que a rede concedia aos melhores do ano, ${ }^{47}$ em suas várias categorias: “O mais entendido” era concedido a um "bofe”. Um relato ${ }^{48}$ informa que o "entendido" compreendia "quatro sexos”; não informados quais seriam. Suponho que correspondessem a homem, mulher, "bicha” e, se esta formava o terceiro, a categoria lésbica seria alocada como “quarto sexo”.

\footnotetext{
46 “A sociedade tem dividido os indivíduos em dois tipos: o ativo (homem), e o passivo (mulher). Essa categorização está extremamente arraigada na nossa cultura e não surpreende que se encontre reproduzida nas relações homossexuais, com os homens classificando-se como 'bofe' e 'bicha', e as mulheres como 'fanchona' e 'lady'. Em ambos os casos, os primeiros seriam 'ativos' e os segundos 'passivos', reproduzindo as relações de dominação vigente entre homens e mulheres” (MACRAE, 1990, 51).

${ }^{47}$ O Snob, n. 18, 1963.

${ }^{48}$ Id., n. 1, 1964.
} 
A rede de sociabilidade aqui estudada, portanto, emprega a palavra "entendido" de maneira abrangente, embora logo venha a ter que readequar sua visão e o uso do vocábulo. A eventual semelhança com os "simpatizantes" de hoje logo se esvai, pela exigência da “comunidade” de participação ativa em suas atividades. Não basta a "tolerância” dos “simpatizantes” com relação às diferenças existentes entre eles; é preciso ser um “deles”. Os “entendidos”, portanto, são aqueles que comungam de igual ponto de vista e, no caso dos “bofes”, têm também participação ativa no “mercado sexual”.

Goffman (1988, p. 37) faz referência à categoria “informados”, que explica parcialmente essa atuação. Esse conceito engloba:

os que são normais, mas cuja situação especial levou a privar intimamente da vida secreta do indivíduo estigmatizado e a simpatizar com ela [...] Os "informados" são os homens marginais diante dos quais o indivíduo que tem um defeito não precisa se envergonhar nem se autocontrolar, porque sabe que será considerado como uma pessoa comum.

Dessa maneira, os sujeitos que carregam esse atributo são considerados “de dentro”, ainda que não participem das condutas sexuais estabelecidas. A rede em estudo compreende, dessa maneira, as mulheres que participavam de suas atividades cotidianas (seriam as “informadas”); os “bofes”, considerados “entendidos”, entretanto, além de ser “informados”, devem participar efetivamente do "mercado sexual" que a rede promove. Isso não quer dizer que em seu meio não possam ter existido "informados”, conforme Goffman sugeriu, mas esses não eram considerados “entendidos” pela rede.

Essa “comunidade entendida” estabelece um modo de vida que, num primeiro momento, inclui os encontros afetivos/sexuais de "bicha” e "bofe”, seus interesses em concursos de misses, seus modos peculiares de autorrepresentação com características femininas, delicadas, elegantes e a preocupação em preservar esses valores em sua "sociedade".

Assim, do ponto de vista das "bichas" - agentes articuladores dessa rede -, a categoria “entendido” tem um significado distinto daquele encontrado na network, pesquisada por Guimarães (2004) nos anos 1970, na qual a autora aponta a emergência de uma nova identidade, que se distingue da "bicha” e do "bofe”.

Nesse momento (1963-1964), os encontros amorosos e/ou sexuais dos participantes da rede envolviam dois personagens com arranjos de gênero distintos: a "bicha” e o "bofe". Conformados a uma "subcultura”, não eram, no entanto, sujeitos isolados; compartilhavam 
com a sociedade maior a crença na divisão rígida de papéis comportamentais segundo o gênero. Alguns relatos, porém, sinalizavam condutas dentro do próprio grupo que não seguiam o roteiro preestabelecido.

Em 1965 e 1966, novas atuações identitárias são manifestadas de maneira contundente dentro da rede, tendo o recém-chegado colunista Pantera como porta-voz. Com atuação diferente da maioria dos componentes das turmas, ele não se considera "bicha”, mas só se relaciona sexual e afetivamente com homens, o que, naquele cenário, colocava em xeque sua identidade masculina e a de seu parceiro também. Em defesa de seu "caso", Pantera responde a uma colunista: "Não me consta que o Ed seja boneca, pois foi meu caso durante muito tempo e jamais desconfiei (ou falei) isto dele. Eu é que tenho muitas vezes passado como tal, exatamente por ter tido um ‘caso’ com uma pessoa que não deixa dúvidas.”

A palavra “caso” passa a substituir “casamento” (ou “noivado”), que designava frequentemente a parceria afetivo-sexual entre uma "bicha” e um "bofe”. Os novos sujeitos do grupo não aceitam designações absorvidas daquelas vigentes na sociedade maior - sua parceria e parceiro agora eram “caso”. Essa denominação já era encontrada nos relatos do jornal em 1963, mas com pouquíssima frequência, preferindo-se então “casamento”, “noiva”, “marido" e correlatos.

Esses "novos atores” procuram outros "iguais” em oposição às "bichas”, que procuram o "diferente”. São homens que não se conformam em ter que se adequar aos modos e maneiras femininos das "bichas”, gerando uma crise de significação identitária na “comunidade”, que tem dificuldade em assimilá-los.

Para minimizar esse impasse, inventou-se a categoria "entendido passado a ferro”, ou seu correlato "bofe passado a ferro", com que se procurava diferenciá-los do "homem de verdade”. "Bicha” faz par com "bofe”, e aqueles, em princípio, entre si. Nada, porém, era simples, e acusações de manipulação identitária ocorreram, sendo imediatamente comunicadas a todos - o controle de informação sobre si era fundamental para preservar a impressão identitária que queriam passar. Alguns exemplos de circulação de informação (verdadeiras ou falsas) sobre a atuação dos atores que os conformavam a essa nova identidade aparecem nas colunas de $O$ Snob:

[1] Não sabemos o certo, mas que ainda vai acontecer algo entre dois famosos bofes, lá isso vai. Eles se olham tanto (n. 4, 1965).

[2] Valdyr e o Guilherme, dois "bofes" passados a ferro se aborreceram, porque um queria comer o outro. O Guilherme não fez segredo disso, por isso o Valdir passou todo o pic-nic aborrecido (n. 21, 1965). 
[3] Dizem a boca pequena que existe um bofe caso de uma amiga que é passado a ferro. Será que está virando moda? (n. 21, 1965).

[4] A COMÉDIA DOS EQUÍVOCOS - Ailton e Mario, tiveram um ligeiro "affair" durante dois dias de carnaval. Quem era quem, perguntavam um ao outro, quando no $3^{\circ}$ dia, descobriram que todos os dois tinham as mesmas intenções. O caso foi desfeito... (n. 2, 1966).

[5] NOVO CASO - Valdir e a Pantera estão de caso e é com surpresa geral que todos comentam. Muitos querem saber finalmente em que ferro o Valdir passa a sua roupa, pois quando vai dançar sempre prefere os BOFES... (n. 2, 1966).

Ainda que de maneira obscura, Pantera tenta compreender e explicar essa nova conduta sociossexual: ${ }^{49}$

O ENTENDIDO PASSADO A FERRO (E.P.F.) é o assunto mais vasto no mundo homossexual. $\mathrm{O}$ ativo e o passivo encontram aí o estágio de qual caminho deve seguir: bofe? bofeca? Boneca? ... e as vezes pensam tanto que nascem, vivem e morrem dentro desse estágio quase que preocupado, porque ele só tem uma preocupação quando vai para uma cama: NÃO SER POSSUIDO DE JEITO NENHUM, mesmo se um desejo repentino apareça não se sabe de onde. Alguns (se não conseguem possuir o seu acompanhante) topam a brincadeira (quebração) dentro de suas normas e leis, sendo que muitas vezes abrem algumas exceções.

Outro colunista (Bianca Marie), seu maior opositor, expõe seu ponto de vista de maneira clara: “o meu objetivo é ser mulher de um homem só, jamais pretendi ser o homem do ano, porque sou pintosa demais e não acredito em homens passados à ferro, ou vulgarmente como se comenta por aí - ENTENDIDOS.”50

As retaliações que a rede promoveu aos "entendidos” foram severas. Seus atributos masculinos foram desacreditados internamente, conformando-os a uma identidade desacreditável. Essa violenta resposta à suas atuações seguiu o roteiro preestabelecido pela sociedade maior: duvidava de sua masculinidade, associava o ato de ser penetrado à condição de mulher (por isso, os "entendidos passados a ferro" manipulam a informação dessa condição), chamava-os no feminino, tudo isso mediante fofocas noticiadas no jornal e disseminadas em suas relações cotidianas.

É óbvio, não foi só dentro da rede que esse novo personagem se apresentou; nas “pegações”, um antigo problema agora agravado impunha-se às "bichas”: não serem “enganadas” pelos “falsos bofes”. A maneira como a rede respondeu a essa manifestação, entretanto, foi singular. Várias situações pitorescas foram relatadas no jornal, como a do conto

\footnotetext{
${ }^{49}$ O Snob, n. 1, 1965.

${ }^{50} \mathrm{Id}$, , n. 12, 1966.
} 
anedótico em que Pantera revela a situação de uma "bicha” que na "caça” ao "bofe” só se depara com sujeitos que, mais rápidos do que "ela”, na primeira oportunidade viram-se de bruços para ser penetrados. "Ela estava com muita pressa, pois há muito tempo não encontrava nada, ou melhor, encontrava, mas era para fazer papel de bofe”, conclui.

Em outra trincheira estavam os "bofes", que viviam, agora internamente, uma identidade desacreditável não só pelas “bichas”, mas principalmente pelos “entendidos”. Exemplifico com uma fofoca lançada por Pantera: "Existe um bofe famoso que está andando com umas calças tão justas, que já está recebendo apelidos adoráveis: Maria Felix e Magali são os mais recentes. Se a esposa dele sabe disso... vão voar penas.”51

Nessa nova classificação em que a aparência externa não denota a posição sexual do “outro”, em que os comportamentos sexuais vão-se dissociando dos papéis de gênero, deixa, pouco a pouco, de ter relevância a atuação sexual "passiva” ou "ativa” para determinar a identidade do sujeito. A homossexualidade começa a ser compreendida como "encontro" entre iguais, independente do papel sexual "ativo" ou "passivo": se dois indivíduos do mesmo sexo se relacionam sexualmente, são ambos considerados homossexuais, independente das técnicas sexuais (penetrar ou ser penetrado) de que façam uso ou do papel de gênero que possam assumir. Na rede, porém, isso não é consensual.

A prática sexual de ser penetrado tem significados que deterioram essa conduta, compreendida como não-máscula. Era corrente a associação dessa técnica sexual à categoria “feminino".

Os componentes da rede ainda estão fortemente influenciados por essa perspectiva, pois, ao que tudo indica, o papel que estabelecem no ato sexual poderia desmoralizar perante a rede, tanto o "entendido passado a ferro" quanto o "bofe", levando-os a serem definitivamente alocados, no campo feminino, como "bichas". Os novos atores tentam ao máximo preservar seus "bastidores”, controlando as informações pessoais. Pantera, ao anunciar seu "entendimento" com outro homem, assim se expressa: "HÉLIO [Pantera] E EDSON completaram no dia 7 mais um ano de entendimento. Não podemos noticiar Sr. e Sra. porque até hoje ninguém sabe como os dois se entendem [...] Agora Niterói está esperando um sair de bolsinha para resolver de vez esta questão.”52

Observo que, nesse início do debate interno, eles se classificavam como "bicha", “bofe” e “entendido”, com características distintas, diferentemente de 1963-1964, quando

\footnotetext{
${ }^{51}$ O Snob, n. 11. 1965.

${ }^{52}$ O Snob, n. 4, 1965.
} 
todos eram considerados "entendidos". O jogo "passivo/ativo", entretanto, ainda os confunde. Ora é o comportamento sexual, ora são os papéis de gênero que os distinguem.

O debate gerado, tanto por Pantera quanto pelos casos dos "entendidos passados a ferro”, relatados em $O$ Snob, somado aos “enganos” a que as "bichas” estão submetidas em suas parcerias sexuais, promoveu disputa pela hegemonia de representação identitária, destacando-se, nesse processo, o propósito de se restabelecer os roteiros anteriores.

As "bichas” tentam levar para seu campo de atuação os “desviantes”, tentando reenquadrá-los na dicotomia "bicha/bofe”; por sua vez, os “entendidos” tentam levar para seu campo de atuação os "bofes”, questionando sua atuação. Dois adágios, muito usados internamente, exemplificam essa última situação: “Em terra de bicha, quem tem bofe tem dúvida” ou “O bofe de hoje é a boneca de amanhã”.

Ainda que perdendo um parceiro em potencial, a maioria das "bichas" prefere que aquele tipo se enquadre como "bicha" e comece a se comportar como tal, pois preserva sua atuação e a do "bofe", que teria então sua identidade restabelecida, sem risco de ser “confundido” com um portador de identidade desacreditável.

Apesar da contestação quanto à atuação dos “entendidos”, a rede mostrava-se ambígua ao classificá-los: se nos prêmios de melhores do ano eram alocados na ala masculina, volta e meia eram caracterizados no campo feminino.

A princípio, porém, a rede distingue esses atores, conformando-os em três espécies distintas: a "bicha”, o “entendido passado a ferro" e o "bofe”, sem abdicar totalmente da expressão “entendido” para classificar todos.

Inferi essas distinções e disputa pela categoria “entendido” também na modificação do lema do jornal, que fora adotado em setembro de 1964. O Snob ${ }^{53}$ tomou como mote de afirmação de um modo de vida sintetizado na frase: "Um jornal informativo para gente entendida. Um jornal para gente bem. Um jornal para você que é de bom gosto.” Esse lema acompanhou a publicação até o n. 6 de 1967; nas edições posteriores, ele não aparece, à exceção do n. 11 de 1967. No entanto, o mais significativo, no meu entender, foi a reincorporação da frase no n. 2 de 1968, mas, com importante mudança: a supressão da expressão "gente entendida” do slogan original, que, até o último número, passou a ser: "Um jornal informativo para gente bem. Um jornal para você que é de bom gosto”. Suponho que essa alteração tenha resultado do embate de significados que durou de 1965 a 67, período ao

\footnotetext{
${ }^{53}$ N. 12, 1964.
} 
longo do qual a categoria "entendido" deixou de representar a totalidade dos componentes da rede e, consequentemente, perde sua força.

Nos dois últimos anos, evidencia-se a dificuldade do Grupo Snob no uso da palavra “entendido”, que apareceu muito fracamente nos dois números de 1969, só empregada pelo “representante” dos “entendidos” (Gato Preto) ou nos relatos de antigos participantes, nostálgicos do significado original.

O primeiro passo para a ressignificação identitária foi dado com a mudança das nominações no feminino; apesar dessa “transformação”, entretanto, ainda havia distinção em relação aos "bofes”; de qualquer forma, desse movimento inicial decorreu forte aproximação com os “entendidos”, à revelia das diferenças entre eles, como sugere a argumentação de uma "bicha":

Não quer dizer que queiramos "virar" homens, apenas encaramos a realidade de nossa homossexualidade, pois mulher nós também não somos: temos um órgão genital masculino que, a revelia de alguns, funciona plenamente, embora com pessoa do mesmo sexo: vestimo-nos com trajes masculinos [...] temos o que é mais importante, a aparência física masculina, porque então tratarmo-nos por Christines, Denizes, Pauletes etc.

Eles, portanto, ainda não se colocam no plano masculino, como os “entendidos”, posto que a homossexualidade não era considerada atributo de "homem"; estão a meio caminho entre a ideia do "terceiro sexo" e as classificações do homossexual, que não o vinculariam à “inversão”.

Corrobora essa observação o fato de que eles continuam oferecendo os prêmios no masculino para "bofes” e “entendidos” e, no feminino, para “elas”(?), criando uma incongruência - não são mulheres, não são homens, não são “entendidos”, não são “bichas”. O que são? Tentam imprimir nova categoria identitária, a gay, cujo significado, na rede, ora engloba os “entendidos” e as "bichas”, ora apenas estas últimas. Como as "bichas” não abdicavam por completo da ideia do "terceiro sexo", nesse momento elas se distanciam dos “entendidos” e, nesse contexto, só “elas” são inseridas naquela categoria.

Resumindo, a “comunidade entendida”, em crise, não pode mais representar todos os seus componentes da mesma maneira, pois a categoria “entendido” estava sendo apropriada por um grupo específico. Como estratégia para restituir o significado anterior, a rede formula nova categoria que a todos represente: a "sociedade gay", excluindo definitivamente os "bofes”, a fim de que a atuação da "bicha” não perca seu significado. 


\section{Comentários Finais}

O processo de mudanças que a rede sofreu em sua trajetória gerou grande embate interno. $O$ Snob expõe as divergências sobre a nova identidade emergente e, nessa disputa, “entendidos" e "bichas" entrincheiravam-se em campos opostos, e a estes últimos se somavam os "bofes".

Os roteiros sexuais preconizavam certos papéis de gênero e certas práticas sexuais que passam a ser questionadas por parte da rede. Agildo Guimarães ${ }^{54}$ assim expõe essas diferenças e as mudanças por que passaram as relações "bicha/bofe":

Na nossa época era bicha e bofe; a diferença do bofe naquela época é que [...] nosso pênis não era tocado [...]. Na época, "bicha” era mulher.

Nós tínhamos o cuidado de não encostar o nosso pênis nos bofes. Se o bofe desse para [o parceiro], ele terminava [...]

Tinha um casal [...] eles realmente eram gays; um era noivo, o outro era o "amigo" do noivo. Influência americana. Eram motivo de comentários esses meninos, que eram gays [...] Na época eles eram considerados bofes.

Na nossa cabeça tinha a diferença entre bofe e bicha. Isso [Os novos arranjos de gênero] no início nos assustou.

Na época não tinham duas bichas... Podiam até ter relações, mas nunca foi...

Quando conheci Jair [nome fictício], era o tipo de bofe entre aspas [o próprio entrevistado solicita aspas, pois, hoje, sabe que Jair é gay], era o bofe que considerava a gente. Na época era o "bofe" perfeito. Quando eu soube que estava namorando um bofinho eu fiquei não horrorizado, mas surpreso. Na realidade ele não queria uma bicha, ele queria um gay.

Desliguei-me daquela coisa de bicha.

Os relatos de $O$ Snob também mostram essas mudanças e os conflitos que elas geraram. Em entrevista, ${ }^{55}$ um “homem verdadeiro” e uma “boneca” expõem suas posições sobre essa nova maneira, mais “igualitária” de se conceberem as relações entre dois homens. A pergunta da entrevistadora recai sobre a veracidade do adágio que circula pela rede: “ $\mathrm{O}$ bofe de hoje é a boneca de amanhã.”

O “bofe” entrevistado era “casado” com uma "bicha”; defendendo sua posição de "homem verdadeiro" explica que não existe meio termo, pois “quando um homem é homem... é homem mesmo", e que exemplos do contrário seriam casos de assunção tardia daqueles que sempre foram “bonecas”. Prosseguindo, expõe a situação por que passou ao ser "pego" por um sujeito e com quem foi ter relações sexuais; ambos se revelam então “homens” (isto é,

\footnotetext{
${ }^{54}$ Entrevista concedida ao autor. Rio de Janeiro, 29 jul. 2007.

${ }^{55}$ O Snob, n.11, 1967.
} 
“ativos”), e o “jogo acabou zero a zero”, porque ele não aceitava “quebração” 56 nem com a “esposa”. Com as referências que ainda traz dos primeiros anos sobre o que é ser "entendido”, ele argumenta: “mesmo assim, gostaria de receber o prêmio de O mais entendido do ano”. Até 1964/65, o significado de “entendido” abrangia todos aqueles que participavam da “comunidade".

A “boneca” entrevistada também não concorda com o ditado, usando argumentação semelhante à do primeiro entrevistado. Para confirmar a raridade da situação, “ela” afirma que nunca teve "a desdita de pegar uma boneca pensando que fosse bofe".

Na realidade, os dois entrevistados associavam a identidade sexual aos comportamentos sexuais: o primeiro chegou a ir para a cama com um homem que procurava um parceiro masculino (como o entrevistado), mas que fosse “passivo”. E o segundo informava a possibilidade de encontrar um homem masculino que pudesse ser “passivo”. Para ambos, esses dois seres masculinos, quando encontrados, por serem “passivos”, seriam "bichas".

Gato Preto em outra entrevista ${ }^{57}$ sobre o mesmo adágio também se contrapõe a essa ideia, mas com argumentação diferente: "não creio nesta história porque conheço muita gente (por experiência própria) que nada tem de boneca e na cama são mais passivas que muitas”. Em sua opinião o sujeito seria “entendido” e não “bicha”.

Têm-se aqui, portanto, duas posições divergentes, uma justificando as diferenças identitárias como produto de seu comportamento sexual, “ativo” ou "passivo”, outra associando-as aos papéis de gênero disponíveis, independente da posição assumida sexualmente.

Esta divergência de concepção identitária perpassa várias colunas do jornal, com muitos comentários que desacreditavam as ações dos sujeitos que se apresentavam como “entendidos”; a dúvida (ou discórdia), porém, foi implantada na rede de maneira irremediável, acentuada pela entrada de novos participantes que se identificam com a nova noção de “entendido”, perturbando os refratários.

Em entrevista ${ }^{58}$ anterior, esse dilema foi explorado nos seguintes termos: "É necessária e autêntica uma terminologia e maneiras femininas para se afirmar como

\footnotetext{
${ }^{56}$ O significado de "quebração" não se revela muito claro pela leitura dos jornais; de qualquer maneira, seria algo entre a troca de posição sexual dos parceiros e, o que acho mais provável, o uso de técnicas sexuais diversas (de acordo com a "sensibilidade" de um ou outro), excluindo a penetração. Em entrevista de 18/01/2010, Jair informa que tem a ver com a expressão "quebrar louça" quando dois "entendidos" ou "bichas" saem para "transar".

${ }^{57}$ O Snob, n.6, 1968.

${ }^{58}$ Id., n. 7, 1967.
} 
personagem no ambiente 'gay’?” E “No 'sexo', é preciso um ativo e um passivo, ou uma homogeneidade”?

Esses novos personagens, diferentemente da maioria dos participantes, buscavam relação mais “igualitária”, da qual o “novo” conceito de “entendido” emerge com significado diferente daquele que a rede produzia até 1964.

Sublinha-se, assim, que fica cada vez mais evidente para parte da rede que determinadas práticas lhes atribuem uma nova condição, designada "entendido" no sentido que Fry (1982), Guimarães (2004) e MacRae (1990) capturaram em suas pesquisas.

Entretanto, até 1968, a postura do jornal diante dessa questão é pendular (ou cuidadosa). É nesse ano que a nova direção retira a expressão "gente entendida” de seu slogan, tentando apaziguar as relações entre seus componentes. Além dessa disputa pela hegemonia de representação identitária, há outra "guerra” na rede, cujas trincheiras são os diversos jornais, envolvendo muitas fofocas a respeito da direção dos jornais e forte disputa de prestígio.

As posições, no entanto, se radicalizam por meio de "contra-ataque”. As acusações dirigidas aos efeminados tornaram-se mais agressivas, e a aceitação pela sociedade maior passa a ser a moeda de troca para justificar certa postura. Em entrevista ${ }^{59}$ ao jornal, Gato Preto afirma que a aceitação dos homossexuais pela sociedade seria mais plena se não fosse “esse negócio de homossexual querer agir como mulher numa frescura excessiva”.

Ao longo dos anos em que esse debate foi travado, Gilk ${ }^{60}$ posicionou-se como mediador, mas não deixou de se opor a uma rigidez de identidade que a todos englobasse. A versatilidade para ele era a chave, buscando "naturalidade” sem exibicionismo.

Vários personagens da rede foram entrevistados ou escreviam textos em que discorriam sobre a homossexualidade. Dois deles me chamaram atenção: um pela conotação social (moral); o outro, por apoiar-se na ordem médica. Nos dois casos, no entanto, o "homossexualismo" é tratado como problema.

Na época atual, não se combate [o homossexualismo] como algo vergonhoso, mas sim aceita-se como um problema que não tem solução $(O$ Snob, n. 7, 1968).

Dentro de uma definição médica mais ampla, o homossexualismo pode significar o contato físico entre duas pessoas do mesmo sexo ou uma reação psicológica, produzida sem o contato físico. Esta reação pode ocorrer em pensamentos, olhares, lembranças de experiências passadas ou antecipações

\footnotetext{
${ }^{59}$ Id., n. 6, 1968.

${ }^{60}$ Agildo Guimarães, que tinha como pseudônimo feminino Gilka, passa a adotar uma nominação no masculino, Gilk.
} 
de futuras. É frequente que as duas reações se deem juntas, mas há casos em que ocorrem separadamente. Há homens que não teriam coragem de consumar o ato físico com outro homem, mas em pensamento comprometem seriamente sua heterossexualidade (O SNOB, n. 7, 1968).

Seguindo os relatos de $O$ Snob, observa-se, a partir de 1968, que aquelas duas identidades, até então distintas, vão ganhando novo significado e percebe-se a produção de um discurso de unificação na categoria "homossexual” que comportaria os dois tipos de sujeito (excluindo os "bofes”): os que podiam ser identificados pela rede como aqueles que faziam “distinção de sexo", ${ }^{1}$ compondo a relação bicha/bofe (sendo somente o primeiro qualificado como homossexual), e os que "não faziam essa distinção" na formação de pares sexuais, classificados pelos grupos como “entendidos passados a ferro”, ou somente “entendido”, que também seria considerado homossexual.

Em 1969, os integrantes da rede centram os debates nas nominações masculinas x femininas ${ }^{62}$. Observo que as expressões usadas no jornal apontam que a categoria “entendido” ainda era motivo de disputa, escolhendo-se o termo gay para a designação identitária.

Gay tornou-se a expressão desse momento e, nos dois últimos números de $O S_{n o b}{ }^{63}$, apareceu associada a “mundo”, “sociedade”, “movimento”, jornalismo”, “união”, “imprensa”, “social” e “clã”, ainda que também fossem usados “homossexual”, "homossexualismo” e "homossexualidade”. Entretanto, nesse momento, o fiel da balança já se estabilizara para a consolidação das relações “igualitárias”, expressa pela categoria “entendido”.

Essas mudanças refletiram-se internamente nos espaços de sociabilidade e nas parcerias sexuais já estabelecidas com assunção de novas possibilidades. Tentei demonstrar que a forma de sociabilidade empreendida pelos grupos em estudo estava diretamente ligada às representações dos papéis de gênero. Analisando os diálogos que esses grupos promoviam com as normas estabelecidas pela sociedade heterocentrada, identifiquei a existência de experimentos originais em busca de um "corpo homossexual normal”.

Assim, nas tentativas de escapar ao rótulo de "anormal”, empreenderam políticas identitárias capazes de reorganizar suas ações de maneira afirmativa - fonte de direitos -, já vislumbrando a possibilidade do surgimento de organizações que pudessem lutar externamente pela legitimação de suas demandas. No entanto, parte do público de $O$ Snob não

\footnotetext{
${ }^{61}$ O Snob, n. 8, 1968.

62 "Dentro de uma sociedade restrita e acondicionada por um sem número de fatores marginalizantes [...] numa sociedade que se constrói do medo e da revolta e por si mesma eivada de preconceitos e recalques, de uma agressividade mal canalizada e assim sendo toma uma forma antropofágica, canibal. Ao não aceitarmos mais o homossexualismo como uma caricatura do feminino, porque estamos conscientes que isto não passa de falta de informações e a necessidade de uma melhor conscientização” ( $O$ SNOB, n. 2, 1969).

${ }^{63}$ O Snob, n. 1 e 2, 1969.
} 
estava ainda imbuída das mudanças das condutas sexuais nem da oportunidade de ampliar sua visibilidade para a sociedade externa. Sabia, provavelmente, que não era nem o lugar nem a hora, pois o clima político não favorecia a liberdade de opinião e de livre manifestação.

\title{
HOMOEROTIC SOCIABILITY AND IDENTITY RELATIONS: the case of journal $O$ Snob (Rio de Janeiro, decade of 1960)
}

\begin{abstract}
This paper studies a homoerotic sociability network in Rio de Janeiro in the decade of 1960 through an analysis of reports contained in the journal $O$ Snob (1963-1969) produced by a group that formed this network and that circulated among its participants. This is an investigation of identity constructions that those characters held in a sociability area segregated by the larger society but, at the same time, in dialogue with it. Analyzing issues commented internally by these groups with the backdrop of the prevailing norms of heterocentric behavior in the period, I identified the existence of original experiments in search of a "normal homosexual body". Sociosexual changes promoted by these experiments reflected in their sociability spaces and in sexual partnerships, facilitating the emergence of new sexual and/or emotional possibilities. So, I try to demonstrate that the form of integration undertaken by the study groups was directly linked to an inflexibility of gender roles of the time, and, over time, it started to detach from this rigidity in order to built new ways of acting. The study of the peculiar trajectory of groups that formed the network, linking it to the identity movements of the time, can contribute to discussions of individual rights history, specifically the struggle for sexual equality, and the debate over gay occupying spaces.
\end{abstract}

Keywords: Homosociability. Gender identities. Segregated spaces. Gay press.

\section{Referências}

CÂMARA, C. Cidadania e orientação sexual: a trajetória do grupo Triângulo Rosa. Rio de Janeiro: Academia Avançada, 2002.

COSTA, J. F. A inocência e o vício: estudos sobre o homoerotismo. Rio de Janeiro: RelumeDumará, 1992.

COSTA, R. S. M. Sociabilidade homoerótica masculina no Rio de Janeiro na década de 1960: relatos do jornal O Snob. Rio de Janeiro: Programa de Pós Graduação de História, Política e Bens Culturais (PPHPBC); Centro de Pesquisa e Documentação de História Contemporânea do Brasil (CPDOC); Fundação Getulio Vargas (FGV), 2010. Disponível em: http://virtualbib.fgv.br/dspace/bitstream/handle/10438/6564/CPDOC2010Rog\%C3\%A9rioS MartinsCosta.pdf?sequence $=1$.

ERIBON, D. Reflexões sobre a questão gay. Rio de Janeiro: Companhia de Freud, 2008. 
FRY, P. Para inglês ver: identidade e cultura na sociedade brasileira. Rio de Janeiro: Zahar, 1982.

GAGNON, J. H. Uma interpretação do desejo: ensaios sobre o estudo da sexualidade. Rio de Janeiro: Garamond, 2006.

GOFFMAN, E. Estigma: notas sobre a manipulação da identidade deteriorada. Rio de Janeiro: Livros Técnicos e Científicos, 1988.

GUIMARÃES, C. D. O homossexual visto por entendido. Rio de Janeiro: Garamond, 2004.

GREEN, J. N. Além do carnaval: a homossexualidade masculina no Brasil do século XX. São Paulo: Unesp, 1999.

MACRAE, E. A construção da igualdade: identidade sexual e política no Brasil da abertura. Campinas: Unicamp, 1990.

MISSE, M. O estigma do passivo sexual: um símbolo de estigma no discurso cotidiano. Rio de Janeiro: Achiamé, 1979.

SILVA, J. F. B. Homossexualismo em São Paulo: estudo de um grupo minoritário. In: GREEN, J.; TRINDADE, R. (Org.). Homossexualismo em São Paulo e outros escritos. São Paulo: Unesp, 2005. p. 41-177. Primeira edição publicada em 1957.

VANCE, C. S. A antropologia redescobre a sexualidade: um comentário teórico. Phisis: Revista de Saúde Pública. Rio de Janeiro: UERJ-IMS, v. 5, n. 1, 1995. p. 7-31. 